\title{
Pathophysiological Role of Adiponectin, Leptin and Asymmetric Dimethylarginine in the Process of Atherosclerosis
}

\author{
Daniela Iv. Koleva ${ }^{1,2}$, Maria M. Orbetzova ${ }^{1,2}$, Julia G. Nikolova3 ${ }^{3}$ Tanya I. Deneva 4,5 \\ ${ }^{1}$ Section of Endocrinology, Second Department of Internal Diseases, Faculty of Medicine, Medical University of Plovdiv, Plovdiv, \\ Bulgaria \\ ${ }^{2}$ Clinic of Endocrinology, St. George University Hospital, Plovdiv, Bulgaria \\ ${ }^{3}$ Department of Physiology, Faculty of Medicine, Medical University of Plovdiv, Plovdiv, Bulgaria \\ ${ }^{4}$ Department of Clinical Laboratory, Faculty of Pharmacy, Medical University of Plovdiv, Plovdiv, Bulgaria \\ ${ }^{5}$ Clinical Laboratory, St. George University Hospital, Plovdiv, Bulgaria
}

\section{Correspondence:}

Daniela Iv. Koleva, Section of Endocrinology, Second Department of Internal Diseases, Faculty of Medicine, Medical University of Plovdiv, 15A Vassil Aprilov St., 4002 Plovdiv, Bulgaria

E-mail: nelka_medicine@abv.bg Tel: +359 898664113

Received: 21 July 2015

Accepted: 07 June 2016

Published Online: 12 Oct 2016

Published: 23 Dec 2016

Key words: adiponectin, leptin, asymmetric dimethylarginine, endothelial dysfunction, adipose tissue

Citation: Koleva DI, Orbetzova MM, Nikolova JG, Deneva TI. Pathophysiological role of adiponectin, leptin and asymmetric dimethylarginine in the process of atherosclerosis.

Folia Medica 2016;58(4):234-240 doi: 10.1515/folmed-2016-0039
Adipose tissue is recognized as a rich source of proinflammatory mediators that may directly contribute to vascular injury, insulin resistance, and atherogenesis. Many studies have shown that adiponectin has antiatherogenic and anti-inflammatory properties. Adiponectin acts not only as a factor increasing insulin sensitivity, and the protective effect may result from its ability to suppress production of proinflammatory cytokines. It negatively regulates the expression of TNF-alpha and C-reactive protein (CRP) in adipose tissue; reduces expression of vascular and intracellular adhesion molecules (VCAM-1, ICAM-1), E-selectin, interleukin-8 (IL-8). Hyperleptinemia has been linked with the development of hypertension and endothelial dysfunction/atherosclerosis, two main pathophysiological conditions associated with cardiovascular disease development. Leptin-mediated increases in sympathetic nervous system activity may be among the principal mechanisms evoking obesity related hypertension. Leptin stimulates the secretion of proinflammatory cytokines, and increases the release of endothelin-1 (ET-1), which may promote hypertension. Increased serum levels of asymmetric dimethylarginine (ADMA), a physiological regulator of the biosynthesis of nitric oxide (NO), promote the process of atherosclerosis, leading to the occurrence of endothelial dysfunction and cardiovascular disease.

\section{INTRODUCTION}

Recent insights into the basic mechanisms involved in atherogenesis indicate that deleterious alterations of endothelial physiology, also referred to as endothelial dysfunction, represent a key early step in the development of atherosclerosis and are also involved in plaque progression and the occurrence of atherosclerotic complications. ${ }^{1}$

One of the major risk factor for cardiovascular disease is the metabolic syndrome (MS). Its components: dyslipidemia, hypertension, insulin resistance and abdominal obesity are linked with an inflammatory and a prothrombotic state. This could generate the cardiovascular disease, the first changes being the endothelial dysfunction. ED accompanied by inflammation in the vessel wall is characterized by increased lipoprotein oxidation, smooth muscle cell proliferation, extracellular matrix deposition, accumulation of lipid-rich material, activation of platelets, and thrombus formation. ${ }^{2}$

Adipose tissue is no longer viewed as a passive repository for triacylglycerol storage and a source of free fatty acids (FFAs). Mature adipocytes are widely acknowledged as an active endocrine and paracrine organ secreting an ever-increasing number of mediators that participate in diverse metabolic processes. ${ }^{3}$ More recently, adipose tissue is recognized as a rich source of proinflammatory mediators that 


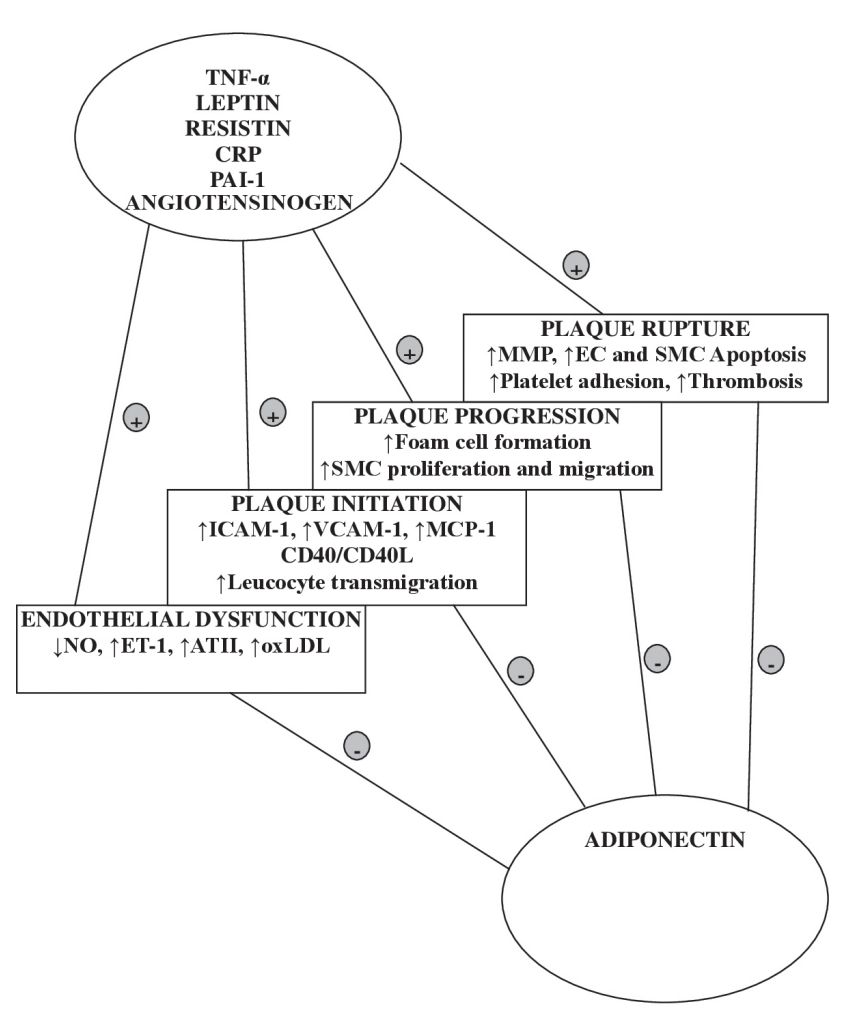

ET-1 - endothelin-1; ATII - angiotensin II; oxLDL - oxidized low-density lipoproteins; MCP-1 - monocyte chemoattractant protein 1; SMC - smooth muscle cell; MMP - matrix metalloproteinase; EC - endothelial cell.

Figure 1. Anti- and proinflammatory adipokines in the process of atherogenesis (adapted from Lau DC et al. ${ }^{28}$ ).

may directly contribute to vascular injury, insulin resistance, and atherogenesis. These proinflammatory adipocytokines, or adipokines, include TNF-alpha, IL-6, leptin, plasminogen activator inhibitor-1 (PAI1 ), angiotensinogen, resistin and C-reactive protein (CRP) (Fig. 1). On the other hand, nitric oxide $(\mathrm{NO})^{4}$ and adiponectin confer protection against inflammation and obesity-linked insulin resistance ${ }^{5}$.

\section{ADIPONECTIN AND ENDOTHELIAL DYSFUNC- TION}

Adiponectin is an adipose tissue-derived adipokine which has protective role in the initiation and progression of atherosclerosis through its anti-inflammatory and anti-atherogenic effects. Adiponectin serum levels are decreased in obesity, type 2 diabetes, patients with coronary artery disease, etc. ${ }^{6}$ The level of circulating adiponectin correlates positively with high-density lipoprotein (HDL) cholesterol, and negatively with inflammatory markers, markers of insulin resistance, triglyceride-rich lipoprotein particles, and other adipokines.
Adiponectin negatively regulates the expression of TNF-alpha and CRP in adipose tissue. On the contrary, its expression is negatively regulated by TNF-alpha and IL-6. Adiponectin reduces expression of vascular and intracellular adhesion molecules (VCAM-1, ICAM-1), E-selectin, IL-8, and monocyte adhesion to human aortal endothelial cells after their stimulation with TNF-alpha. ${ }^{7}$ The proliferation and migration of smooth muscle cells induced by platelet-derived growth factor (PDGF) is abolished or diminished by adiponectin action as inhibition of activation of nuclear factor kappa $\mathrm{B}$ in endothelial cells. This effect is partially mediated by its ability to support the action of cyclic adenosine monophosphate - proteinkinase A system (cAMP-PKA).

In endothelial cells, adiponectin inhibits the production of reactive oxygen species (ROS) induced by high levels of glucose via the above mentioned cAMP-PKA system. Adiponectin inhibits macrophage transformation to foam cells and reduces the intracellular content of cholesterol esters via suppression of expression of scavenger receptors, class A (SR-A). In these cells, adiponectin reduces lipopolysaccharides stimulated TNF-alpha production.

In some recent studies, adiponectin has a positive effect in endothelial homeostasis. It acts as a regulator of the enzyme endothelial nitric oxide synthase (eNOS), which is a key determinant of endothelial function and angiogenesis (the production of NO inhibits the inflammatory response in the arteries), and also promotes phosphorylation of eNOS in endothelial cells, increases its expression and induces NO production after suppression of its activity caused by the effect of oxidized low-density lipoproteins (oxLDL). ${ }^{8}$

There is an increasing number of papers on experimental models that point to the fact that adiponectin plays an important protective role in the development of insulin resistance and diabetes. Severe insulin resistance was seen in adiponectindeficient knockout mice (KOAD) after administration of high fat and/or carbohydrates diets. Administration of adiponectin led to reduced hyperglycemia in the diabetic mice without affecting insulin levels. In another study, increased muscle fatty acid oxidation and reduction of plasma glucose, free fatty acids and triglycerides were observed. Studies on experimental animal models have revealed that the administration of adiponectin has a beneficial action against the development of obesity and atherosclerosis. It seems that adiponectin acts not 
only as a factor increasing insulin sensitivity, and the protective effect may result from its ability to suppress production of proinflammatory cytokines. ${ }^{7}$

In vitro experiments revealed the physiological concentrations of adiponectin inhibited TNF-alpha induced expression of VCAM-1 and ICAM- 1 on the endothelium and exhibited other antiatherogenic effects. In 2008, Vaverková et al. published a study investigating the relationship between adiponectin and serum concentrations of soluble adhesive molecules VCAM-1 and ICAM-1 as well as with markers of insulin resistance and inflammation in patients with cardiovascular disease (CVD) and in dyslipidemic patients at high risk of CVD. ${ }^{9}$ The authors found significant independent positive association of adiponectin with VCAM-1 but not with ICAM-1 serum concentrations in patients with or at risk for CVD. Their expression results in adhesion of circulating leukocytes to the endothelial cells and their subsequent transendothelial migration - an important step in initiation and progression of atherosclerosis.VCAM-1 and ICAM-1 have a different expression pattern and probably different roles in atherogenesis. ${ }^{10}$ Soluble forms of these molecules can be measured in peripheral circulation. The origins of circulating soluble cell adhesion molecules are not entirely clear, but they may derive from shedding or proteolytic cleavage from endothelial cell.

Many studies, including experiments in vitro, animal models and studies in human, have shown that adiponectin has antiatherogenic and anti-inflammatory properties. Low adiponectin levels were found in patients with coronary artery disease (CAD) independently of other risk factors. Therefore, the finding of positive and independent association of adiponectin with the marker of endothelial dysfunction VCAM-1 was surprising. This positive association was present both in patients with CVD and dyslipidemic subjects without CVD, but it was not significant in healthy subjects without dyslipidemia. The authors hypothesize that adiponectin, which accumulates in the arterial wall only in place of endothelial injury and atherosclerotic plaques (that is the same places where VCAM-1 is expressed) may be involved in shedding of ectodomains of VCAM-1 from endothelial surface. This may represent a mechanism by which VCAM-1 effects on the cell surface can be downregulated. In this way, adiponectin could protect vascular wall from adhesion of leukocytes and thus from progression of atherosclerosis. ${ }^{11}$

\section{LEPTIN AND ENDOTHELIAL DYSFUNCTION}

Leptin was one of the first proteins discovered to be secreted from adipose tissue, by the identification and sequencing of the ob gene from the ob/ ob mouse. Daily injection of the peptide in ob/ob mice resulted in a rapid reduction in food intake, body mass and percentage body fat but maintained lean muscle mass, increased energy expenditure and restored euglycaemia and reproductive function, confirming that it has an important role in energy homoeostasis and storage. However, leptin levels were found to be increased in obese subjects, with little or no impact to regulate energy homoeostasis, which coined the well-established phrase 'leptin resistance' in obesity. ${ }^{12}$

Leptin has been implicated in various pathophysiological mechanisms for CVD development.

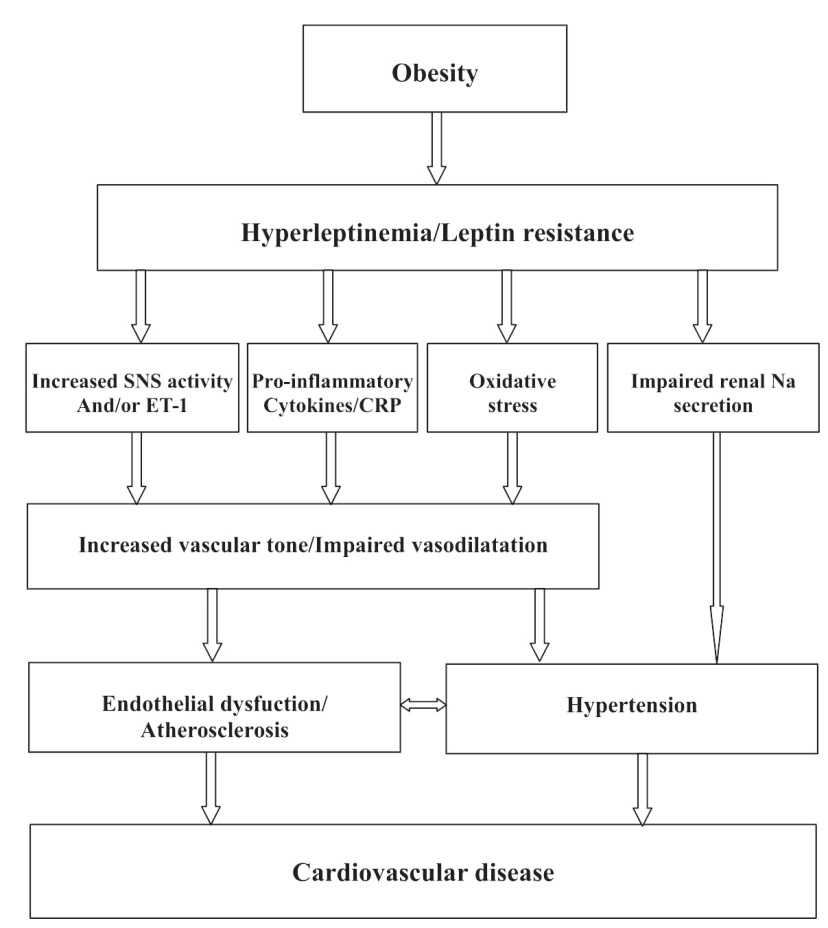

Figure 2. Mechanisms associated with hyperleptinemia and considered to be possible links between obesity and CVD (adapted from Esler $\mathrm{M}$ et al. ${ }^{29}$ ).

Hyperleptinemia has been linked with the development of hypertension and ED/atherosclerosis ${ }^{13,14}$, two main pathophysiological conditions associated with CVD development (Fig. 2). 


\section{MECHANISMS OF ED/ATHEROSCLEROSIS IN A STATE OF HYPERLEPTINEMIA}

HYPERLEPTINEMIA ACTIVATES THE SYMPATHETIC NERVOUS SYSTEM (SNS) AND/OR ET-1

It has been demonstrated that experimental hyperleptinemia acutely increases vasoconstrictory sympathetic nerve activity in healthy humans. Leptin binds to its receptors in various regions of the central nervous system (CNS) - including the hypothalamus - activating neural pathways, decreasing appetite, and increasing SNS activity and energy expenditure. SNS activation by leptin may occur through both local peripheral actions and centrally mediated effects on the hypothalamus - although intact leptin receptors (LRs) and CNS signaling are still required for this response. ${ }^{15}$ Leptin-mediated increases in SNS activity may be among the principal mechanisms evoking obesity-related hypertension.

ET-1 is a 21-amino acid peptide that is mainly produced by the vascular endothelium through the actions of an endothelin-converting enzyme on the endothelial cell membrane. ET-1 causes prolonged smooth muscle-mediated vasoconstriction and hypertension, affects cardiac stimulation in a manner that can indirectly modify cardiovascular function, stimulates aldosterone secretion, decreases renal blood flow and glomerular filtration rate, and releases atrial natriuretic peptide. Because of its powerful vasoconstrictor properties and its effects on intracellular calcium, ET-1 has been implicated in the pathogenesis of hypertension, coronary vasospasm, and heart failure. Leptin has been shown to induce ET-1 in endothelial cells in vitro, and stimulates ET-1 activity in lean subjects in vivo. ${ }^{16}$

\section{LEPTIN AND INFLAMMATION}

Several reports have also demonstrated that leptin possesses proinflammatory cytokine-like properties. It has been demonstrated that high plasma leptin levels up-regulate the expression of monocyte cytokines such as TNF-alpha and IL-6. ${ }^{17}$ Leptin levels are also correlated with CRP in both lean and obese subjects. Furthermore, CRP can impact atherosclerosis development by hampering endothelial NO production - either directly by decreasing endothelial NO expression, or indirectly by increasing ROS production and thus inactivating NO. Leptin may regulate CRP production in the liver both through its effects on IL- 6 and by direct regulation. ${ }^{18}$

\section{LEPTIN AND OXIDATIVE STRESS}

ROS production is enhanced in obesity. Leptin induces oxidative stress in human endothelial cells and mitochondrial superoxide anion production in aortic endothelial cells via augmented fatty acid oxidation. Excess superoxide production may quench $\mathrm{NO}$, thus favoring the formation of ONOO-, which reduces local NO bioavailability. ${ }^{19}$ This may result in the attenuation of dilator responses to NO-mediated agonists, such as acetylcholine (Ach).

HYPERLEPTINEMIA MAY INCREASE VASCULAR TONE AND IMPAIR VASODILATATION

The results regarding the overall effect of leptin on blood pressure have been controversial. It is likely that, with only short exposures, the leptinmediated increase in SNS activity may not be sufficient to cause marked peripheral vasoconstriction and to acutely raise blood pressure. Additionally, impaired leptin-induced NO production might be compensated by endothelium-derived hyperpolarizing factor (EDHF). However, chronic increases in plasma leptin, comparable to those found in severe obesity, can raise blood pressure. This effect is partly because the contribution of EDHF to the hemodynamic effect of leptin becomes inefficient, as well as partly due to the activation of leptininduced renal mechanisms. ${ }^{20}$ In fact, some studies have demonstrated that long-term leptin administration increases both renal sympathetic nerve activity and blood pressure, promoting sodium retention and decreasing natriuresis. ${ }^{21}$ However, in lean rats, leptin-mediated increase of renal sodium excretion was not followed by blood pressure changes. It has been proposed that the lack of effect after acute leptin administration in vivo is related to the concept of selective leptin resistance and the "counterbalance theory". According to this theory, under normal physiological conditions in vivo, the simultaneous vasodilatory and vasopressor effects of leptin counteract each other, making leptin's net hemodynamic effect neutral. ${ }^{22}$ However, in obese hyperleptinemic individuals or subjects with previous endothelial damage, this balance could be disrupted. In such cases, hyperleptinemia may alter vasodilatation capacity and raise blood pressure through SNS activation ${ }^{15}$ and proinflammatory effects $^{17}$, along with co-existing impairment of NO synthesis or NO activity. Following this reasoning, the acute effects of leptin would include both 
vasodilator effects together with SNS stimulation, resulting in an overall neutral effect.

Leptin has also been associated with hypertension via other mechanisms; for example, leptin increases ROS generation in endothelial cells, which decreases the amount of bioactive NO. As mentioned earlier, leptin stimulates the secretion of proinflammatory cytokines such as TNF-alpha and IL-6, and increases the release of ET-1, which may promote hypertension. Interestingly, one study demonstrated a reduction in serum leptin levels with the use of angiotensin-converting-enzyme inhibitors (ACEi) and angiotensin II receptor blockers (ARBs), suggesting a potential interaction between leptin and the ROS for hemodynamic regulation in obesity. ${ }^{21}$

\section{ADMA AND ENDOTHELIAL DYSFUNCTION}

Endothelial dysfunction, a systemic disorder and an early pivotal event in the pathogenesis of atherosclerosis, is characterized by reduced production of nitric oxide (NO) and an imbalance between endotheliumdependent vasodilatation and vasoconstriction as well as antithrombotic and prothrombotic factors. NO maintains the vasodilatory property of endothelium and opposes the effects of such vasoconstrictors like ET-1 and angiotensin II (ANG II). It inhibits leukocyte and platelet activation and aggregation and, together with prostacyclins, helps to maintain the endothelium as a smooth nonthrombotic barrier. ${ }^{23}$

The asymmetric dimethylarginine (ADMA), a by-product of cellular protein turnover, serves as a physiological regulator of the biosynthesis of NO and is believed to be an endogenous competitive inhibitor of eNOS. It is proved that increased serum levels of ADMA promote the process of atherosclerosis, leading to the occurrence of ED and CVD. ${ }^{24}$ Elevated plasma levels of ADMA were demonstrated in patients with diabetes, hypercholesterolemia, hypertriglyceridemia, hypertension, preeclampsia, peripheral vascular disease, congestive heart failure, acute coronary syndrome. ${ }^{25,26}$ ADMA is perceived as a marker of ED, a candidate for a new cardiovascular risk factor or an independent risk factor for cardiovascular morbidity and mortality.

In a study of our clinic, which included 24 women with MS, 38 women with polycystic ovary syndrome (PCOS) and 24 age-matched clinically healthy women, we found significantly higher plasma levels of ADMA in both the women with PCOS and MS $(0.91 \pm 0.32 \mu \mathrm{mol} / 1$, and $0.82 \pm 0.37$ $\mu \mathrm{mol} / 1$, respectively, $\mathrm{p}>0.05$ ) as compared to those in the healthy women $(0.65 \pm 0.35 \mu \mathrm{mol} / 1, \mathrm{p}<0.05)$. No significant correlations between ADMA and age, body mass index (BMI), waist circumference, fasting plasma glucose, fasting immunoreactive insulin (IRI), homeostasis model assessment of insulin resistance (HOMA-IR), lipid parameters and systolic blood pressure in the women with both MS and PCOS were found. In women with MS unlike those with PCOS, the diastolic blood pressure showed a significant negative correlation with ADMA. ${ }^{27}$

\section{CONCLUSION}

Certain adipocytokines, such as leptin, TNF-alpha and adiponectin significantly affect obesity-related metabolic diseases by controlling fat metabolism, energy homeostasis, and insulin sensitivity. Independent of their effects on glucose and fat metabolism, some adipokines have been regarded recently as direct links between obesity and atherosclerosis because of their influence on the function of endothelial cells (the production of NO), arterial smooth muscle cells, and macrophages in vessel walls. The interactions between the adipose tissue, the vascular wall, and the immune system are complex, and these are the key players from which we have to understand the mechanisms implicated in the development of atherosclerosis. In light of recent developments, interventions to decrease inflammation associated with metabolic syndrome are actually developed and hopefully might in the near future be of great benefit in decreasing the 'danger' associated with our modern lifestyle.

\section{REFERENCES}

1. Bonetti P, Lerman L, Lerman A. Endothelial dysfunction - a marker of atherosclerotic risk. Arterioscler Thromb Vasc Biol 2003;23:168-75.

2. Vincent MA, Montagnani M, Quon MJ. Molecular and physiologic actions of insulin related to production of nitric oxide in vascular endothelium. Curr Diab Rep 2003;3:279-88.

3. Ferroni P, Basili S, Falco A, et al. Inflammation, insulin resistance and obesity. Curr Atheroscler Rep 2004;6:424-31.

4. Yan H, Aziz E, Shillabeer G, et al. Nitric oxide promotes differentiation of rat white adipocytes in culture. J Lipid Res 2002;43:2123-9.

5. Kubota N, Terauchi Y, Yamauchi T, et al. Disruption of adiponectin causes insulin resistance and neointimal formation. J Biol Chem 2002;277(29):25863-6. 
6. Shimada K, Miyazaki T, Hiroyuki D. Adiponectin and atherosclerotic disease. Clin Chim Acta 2004;344:1-12.

7. Ouchi N, Walsh K. Adiponectin as an anti-inflammatory factor. Clin Chim Acta 2007;380:24-30.

8. Motoshima H, Wu X, Mahadev K, et al. Adiponectin suppresses proliferation and superoxide generation and enhances eNOS activity in endothelial cells treated with oxidized LDL. Biochem Biophys Res Commun 2004;315:264-71.

9. Vaverková H, Karásek D, Novotný D, et al. Positive association of adiponectin with soluble vascular cell adhesion molecule sVCAM-1 levels in patients with vascular disease or dyslipidemia. Atherosclerosis 2008;197(2):725-31.

10. Blankenberg S, Barbaux S, Tiret L. Adhesion molecules and atherosclerosis. Atherosclerosis 2003;170:191-203.

11. Novotný D, Vaverková H, Karásek D. Adiponectin: a perspective adipose tissue marker with antiinflammatory and anti-aterogenic potential. In: Frank S, Kostner G, editors. Lipoproteins - role in health and diseases. Rijeka: InTech Janeza Trdine; 2012: 862-700.

12. Friedman JM, Halaas JL. Leptin and the regulation of body weight in mammals. Nature 1998;395:763-70.

13. Beltowski J. Leptin and atherosclerosis. Atherosclerosis 2006; 189:47-60.

14. Beltowski J. Role of leptin in blood pressure regulation and arterial hypertension. J Hypertens 2006;24:789-801.

15. Hall JE, da Silva AA, do Carmo JM, et al. Obesityinduced hypertension: role of sympathetic nervous system, leptin, and melanocortins. J Biol Chem 2014;285(23):17271-6.

16. Schinzari F, Tesauro M, Rovella V, et al. Leptin stimulates both endothelin-1 and nitric oxide activity in lean subjects but not in patients with obesityrelated metabolic syndrome. J Clin Endocrinol Metab 2013;98(3):1235-41.

17. Lord GM. Leptin as a proinflammatory cytokine. Contrib Nephrol 2006;151:151-64.
18. Bastard JP, Maachi M, Lagathu C, et al. Recent advances in the relationship between obesity, inflammation, and insulin resistance. Eur Cytokine Netw 2006;17(1):4-12.

19. Pacher P, Beckman JS, Liaudet L. Nitric oxide and peroxynitrite in health and disease. Physiological Reviews 2007;87:315-424.

20. Beltowski J, Wojcicka G, Marciniak A, et al. Oxidative stress, nitric oxide production, and renal sodium handling in leptin-induced hypertension. Life Sciences 2004;74:2987-3000.

21. Beltowski J, Jamroz-Wisniewska A, Borkowska E, et al. Upregulation of renal $\mathrm{Na}^{+}, \mathrm{K}^{+}$-ATPase: the possible novel mechanism of leptin-induced hypertension. Polish Journal of Pharmacology 2004;56:213-22.

22. Brook RD, Bard RL, Bodary PF, et al. Blood pressure and vascular effects of leptin in humans. Metab Syndr Relat Disord 2007;5(3):270-4.

23. Verma S, Anderson TJ. Fundamentals of endothelial function for the clinical cardiologist. Circulation 2002;105:546-9.

24. Koleva D, Orbetzova M, Deneva T. Asymmetric dimethylarginine - a mediator of endothelial dysfunction and its relationship with syndromes of insulin resistance. Endocrinologia 2013;18(1):33-40.

25. Vladimirova-Kitova L. Asymmetric dimethylarginine in hypercholesterolmic patients. Journal of IMAB 2008;11:103-5.

26. Abbasi F, Asagami T, Cooke JP, et al. Plasma concentrations of asymmetric dimethylarginine are increased in patients with type 2 diabetes mellitus. Am J Cardiol 2001;88:1201-3.

27. Koleva D, Orbetzova M, Deneva T. Asymmetric dimethylarginine in women with metabolic syndrome and polycystic ovary syndrome. Endocrinologia 2014;19(3):154-9.

28. Lau DC, Dhillon B, Yan H, et al. Adipokines: molecular links between obesity and atherosclerosis. Am J Physiol Heart Circ Physiol 2005;288(5):2031-41.

29. Esler M, Straznicky N, Eikelis N, et al. Mechanisms of sympathetic activation in obesity-related hypertension. Hypertension 2006;48:787-96. 


\title{
Патофизиологическая роль адипонектина, лептина и ассиметричного диметиларгинина в процессе атеросклероза
}

\author{
Даниела Ив. Колева ${ }^{1,2}$, Мария М. Орбецова ${ }^{1,2}$, Юлия Г. Николова3, Таня И. Денева ${ }^{4,5}$ \\ ${ }^{1}$ Секция эндокринологии, второго отдела внутренних болезней, Факультет медицины, Медицинский университет Плов- \\ див, Пловдив, Болгария \\ ${ }^{2}$ Клиника эндокринологии, Университетская больница «Св. Георги», Пловдив, Болгария \\ ${ }^{3}$ Кафедра физиологии, Факультет медицины, Медицинский университет Пловдив, Болгария \\ ${ }^{4}$ Кафедра клинической лаборатории, Факультет фармации, Медицинский университет Пловдив, Болгария \\ ${ }^{5}$ Клиническая лаборатория, Университетская больница «Св. Георги», Пловдив, Болгария
}

\begin{abstract}
Адрес для кореспонденции: Даниела Ив. Колева, Секция эндокринологии, второго отдела внутренних болезней, Факультет медицины,

Медицинский университет Пловдив, бул. Васила Априлова № 15A, Пловдив, 4002, Болгария E-mail: nelka_medicine@abv.bg Тел.: +359898664113
\end{abstract}

Дата получения: 21 июля 2015 г. Дата приемки: 07 июня 2016 г. Дата онлайн публикации: 12 октября 2016 г.

Дата публикации: 23 декабря 2016 r.

Ключевые слова: адипонектин, лептин, ассиметричный диметиларгинин, эндотелиальная дисфункция, жировая ткань

Образец цитирования: Koleva DI, Orbetzova MM, Nikolova JG, Deneva TI. Pathophysiological role of adiponectin, leptin and asymmetric dimethylarginine in the process of atherosclerosis.

Folia Medica 2016;58(4):234-240 doi: $10.1515 /$ folmed-2016-0039
В свете современных данных доказано, что жировая ткань (ЖТ) представляет собой богатый источник проинфламаторных медиаторов, которые непосредственно могут привести к поражению сосудов, развитию инсулинорезистентности и атерогенезу. Рядом исследований установлено, что адипонектин обладает антиатерогенными и противовоспалительными свойствами. Адипонектин действует в роли фактора, повышающего инсулиновую чувствительность и характеризуется наличием протективного эффекта, обусловленного его способностью подавлять производство проинфламаторных цитокинов. Он супрессирует экспрессию генов на производство туморнекротизирующего фактора альфа (TNF-a) и C-реактивного протеина (CRP) в жировой ткани; понижает экспрессию на производство молекул адгезии сосудистого эндотелия 1 типа и молекул межклеточной адгезии 1 типа (VCAM1, ICAM1), Е-селектина, интерлейкина-8 (IL-8). Гиперлептинемия является состоянием, связанным с наличием гипертонии и эндотелиальной дисфункции (ЭД)/атеросклероза - двух ключевых факторов в развитии сердечно-сосудистых заболеваний (СС3). Обусловленную лептином повышенную активность симпатической нервной системы (CHC) можно считать основным механизмом, провоцирующим развитие гипертонии, связанной с ожирением. Лептин стимулирует секрецию проинфламаторных цитокинов и увеличивает выделение эндотелина 1 (ЭД-1), ведущих к развитию гипертонии. Увеличенные сывороточные уровни ассиметричного диметиларгинина (АДМА) - патофизиологического регулятора в биосинтезе оксида азота (NO), ускоряют процесс атеросклероза, проявляющегося наличием эндотелиальной дисфункции и СС3. 